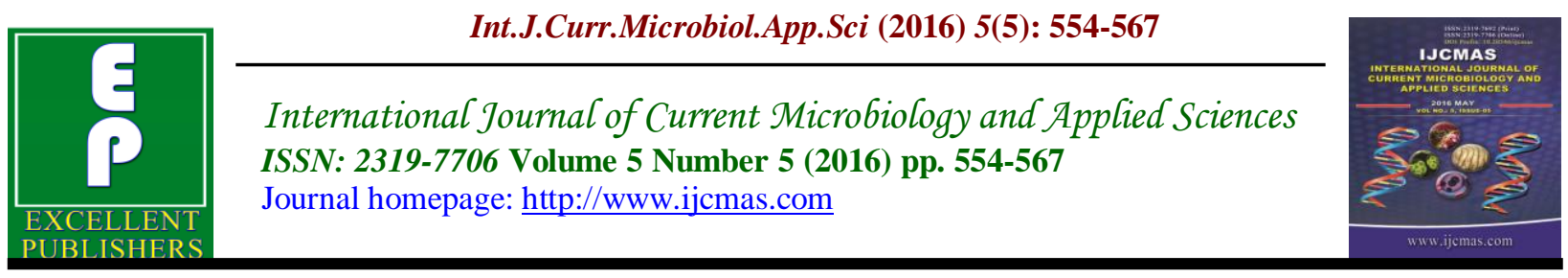

Original Research Article

http://dx.doi.org/10.20546/ijcmas.2016.505.057

\title{
Production of Cyclodextrin Glycosyltransferase by Newly Isolated Alkalophilic Strain of Leucobacter Species
}

\author{
H.S. Hazeena and A. Jayakumaran Nair* \\ Department of Biotechnology, University of Kerala, Kariavattom, \\ Thiruvananthapuram, Kerala, India \\ *Corresponding author
}

Keywords

CGTase, cyclodextrins, alkalophilic, Optimization.

Article Info

Accepted:

18 April 2016 Available Online: 10 May 2016

\section{A B S T R A C T}

Cyclodextrins are cyclic oligosaccharides having applications in various industrial and pharmaceutical companies. Cyclodextrin glycosyltransferase is the enzyme that converts starch into cyclodextrins (CDs). We screened 45 strains of CGTase positive isolates from soil samples collected from different regions of tropical forest of Kerala, India. A new strain of Leucobacter species which produce CGTase was isolated and the culture conditions and media components were optimized for the enhanced production of the enzyme, which synthesize $\alpha$ and $\beta$ cyclodextrins. The organism is found to be alkalophilic as its optimum $\mathrm{pH}$ is above 10 .

\section{Introduction}

Cyclodextrin glycosyltransferase (EC.2.4. 1.19) is an extra cellular enzyme, which converts starch into a group of cyclic oligosaccharides consisting of 6-12 units of glucose units joined by the $\alpha-1,4$-linkages known as cyclodextrins (CDs). Starch molecules are cleaved into short linear oligosaccharides chains and its new reducing ends are joined, transforming it into non-reducing cyclic molecules. The cyclodextrins have a short cylindrical structure, whose interior is hydrophobic consisting of Hydrogen and carbon atoms and exterior is hydrophilic with hydroxyl groups projecting outwards. Because of this special characteristic feature, they are capable of forming inclusion complexes with a veriety of water immiscible organic and inorganic molecules (Abdel-Naby et al., 2011).Thus cyclodextrins are extensively used in guest - host interaction to make high efficient inclusion compounds and have tremendous application in pharmaceutical industries, textile industries, cosmetics, food and agriculture industries. CDs help to increase the solubility in water, increase the stability, increase the controlled release of drugs, flavors, fragrance, mask bad odors and tastes and increase the longevity of volatile compounds (Atanasova et al., 2008; Hamoudi et al., 2011; Marçon et al., 2009; Sian H., 2005 and Wang et al., 2011). 
There are three different types of CDs such as $\alpha, \beta$ and $\gamma$ CDs consisting of six, seven and eight glucose units respectively. The CGTase responsible for the production of each of these CDs is also different. Most of the bacterial CGTase produce all the three types of CDs together. The bacterial CGTase are also classified in to $\alpha-, \beta$ - and $\gamma$ CGTase based on the major type of CDs they synthesize. Enzymes that synthesize predominantly one types of cyclodextrin have great commercial importance as the separation of one type of CDs from the mixture is not economical (Jemli et al., 2007). The quality of CD produced depends mostly on the type of organisms and the purification methods. Therefore new strains of organisms for the CGTase production of CGTase very important for the high quality $\mathrm{CD}$ production as it received great importance in the various industrial sectors (Schmid G, 1989).

CGTase with varying properties are produced to a large scale in a complex medium by bacteria mainly belonging to Bacillus species by submerged culture (Andriana et al., 2002). Alkalophilic microorganism is also known to produce this unusual enzyme that can be used in industrial processes for the production of cyclodextrins. All known CGTases (Bart et al., 2000) produces a mixture of cyclodextrins when incubated with starch. Considering the importance of cyclodextrins and the need for new enzymes with higher efficiency for the synthesis CDs, we attempted to screen out new strain of CGTase producing organisms from its natural sources. In our present study we report the isolation of a new strain of Leucobacter species which produce CGTase and cyclodextrin and the optimization of media and culture conditions for the enhanced production of CGTase, which synthesize $\alpha$ and $\beta$ cyclodextrins.

\section{Materials and Methods}

\section{Microorganism}

We have isolated a new strain of CGTase producing bacteria from the soil of tropical rain forest in Kerala. The isolated organism PK-8 was identified as Leucobacter species by morphological and biochemical methods. The organism was screened and isolated in Horikoshi agar plate and the same media was used for the storage and further culturing of the organism.

\section{Media Composition and Culture Conditions}

Bacteria was grown in Horikoshi media consisting of $1.0 \%$ soluble $\operatorname{starch}(\mathrm{w} / \mathrm{v})$, $0.05 \%$ yeast extract, $0.5 \%$ peptone, $0.1 \%$ K2HPO4， $0.02 \% \quad \mathrm{MgSO} 4.7 \mathrm{H} 2 \mathrm{O}, \quad 0.03 \%$ phenolphthalein, $0.01 \%$ Methyl orange, $1 \%$ $\mathrm{Na} 2 \mathrm{CO} 3$ and $1.5 \%$ agar (for solid media) and $\mathrm{pH}$ was adjusted to 10.5 (11). Culture plates were incubated at $37{ }^{\circ} \mathrm{C}$ for 72 hours. Horikoshi phenolphthalein (PHP) plate was used for detecting the CGTase producing organisms. The morphological characteristics of the isolated strain were determined by Gram's Method.The bacterial strain of Leucobacter specieswas grown in $20 \mathrm{ml}$ of sterile Horikoshi medium (Park et al., 1989). The culture was incubated at $35^{\circ} \mathrm{C}$, constantly agitated at $120 \mathrm{rpm}$ for 18 hours. Overnight grown cultures of 0.5 optical density at $660 \mathrm{~nm}$ was used as inoculum in all the fermentation experiments.

\section{Production of Crude Enzyme}

The organism was inoculated to $100 \mathrm{ml}$ of Horikoshi broth of $\mathrm{pH} 10.5$ in $500 \mathrm{mlErlenmeyer}$ flask. The media was inoculated with $1 \mathrm{ml}$ of $5 \%(\mathrm{v} / \mathrm{v})$ of bacterial inoculum of $0.5 \mathrm{OD}$ at $660 \mathrm{~nm}$. 
The bacterial culture was incubated at $35^{\circ} \mathrm{C}$ in an incubator shaker for 6 days. Samples were withdrawn at specific intervals of time, centrifuged at $5000 \mathrm{rpm}$ for 10 minutes and the supernatant was assayed for CGTase activity and used as crude enzyme solution.

\section{CGTase Assay Method}

CGTase activity was determined by using phenolphthalein assay (Kaneto et al., 1987). Reaction mixture consist of $1 \mathrm{ml}$ of starch solution $(20 \mathrm{mg}$ of soluble starch in $100 \mathrm{ml}$ of $10 \mathrm{mM}$ phosphate buffer - $\mathrm{pH}$ 6.6) and $0.1 \mathrm{ml}$ enzyme solution. The mixture was incubated at $65{ }^{\circ} \mathrm{C}$ for 20 minutes in a water bath. Subsequently $0.5 \mathrm{ml}$ of $0.02 \%$ (w/v) phenolphthalein in $5 \mathrm{mM} \mathrm{Na} 2 \mathrm{CO} 3$ solution was added to the reaction mixture and mixed thoroughly. After 15 minutes, the reduction in color intensity was measured at $550 \mathrm{~nm}$. For each batch of samples blanks lacking the CGTase were analyzed simultaneously. As a standard, the soluble starch and enzyme were replaced by $0.5 \mathrm{mg}$ of $\beta-\mathrm{CD}$ and 0.1 $\mathrm{ml}$ water respectively. A calibration curve was made using $\beta-C D$ in $100 \mathrm{~mm}$ phosphate buffer at pH6.6.One unit of enzyme activity was defined as the quantity of enzyme that produces $1 \mu \mathrm{mol}$ of $\beta$ cyclodextrin per minute under standard conditions.

\section{Cell Biomass Determination}

Cell biomass was determined by estimating the dry weight of the media free cells separated from the cultures. Traces of starch present in the cell culture was removed by treating it with $0.1 \mathrm{ml}$ (1 unit) of $\alpha$-amylase to hydrolyze the residual starch to soluble sugars before pelleting the cells by centrifugation. The cell pellet was washed with distilled water and dried in an oven at $95{ }^{\circ} \mathrm{C}$ for $24 \mathrm{hr}$.

\section{Protein Estimation}

Protein content of samples was estimated by following the method developed by Lowry et al., 1951.

\section{Optimization of Culture Conditions for CGTase Production}

Nutritional components of the media such as carbon sources, nitrogen sources, metallic ions and microelements were optimized by adopting the search technique by varying one factor at a time. Effects of physical factors such as temperature, $\mathrm{pH}$ and agitation speed affecting the production of CGTase were also determined. All the experiments were conducted in $500 \mathrm{ml}$ Erlenmeyer flasks. All the experiments were carried out in triplicate with a control.

\section{Chemicals}

All chemicals, biochemicals and media constituents used in the study were of analytical grade (unless stated otherwise). Soluble starch, sodium carbonate and phenolphthalein were purchased from Merck. Rice starch, corn starch, tapioca starch, potato starch and sago starch were of industrial grade. Yeast extract and peptone were purchased from SRL. Other media constituents used were purchased from Himedia.

\section{Results and Discussion}

\section{Isolation of CGTase Producing Alkalophilic Bacteria}

About 45 bacterial isolates were obtained by the screening of soil samples collected from different places. The isolates showed halo zones around their margin, suggesting possibility of CGTase production. From this 8 positive isolates were propagated in 
alkaline liquid medium and CGTase activity was measured in the culture supernatants (Fig: 1). One of these isolates designated as PK-8 showing the highest CGTase production $(4.056 \mathrm{U} / \mathrm{ml})$, was selected for further screening. This isolate showed the highest clearance zone of diameter $3 \mathrm{~cm}$ in solid alkaline phenolphthalein medium in 24 hrs as a qualitative measurement. Gram staining showed strain PK-8 was gram positive rod shaped with tapering ends. Colonies were circular, raised, golden yellow pigmented. The organism was identified as Leucobacter species.

\section{Optimization of the Culture Conditions}

Fermentation processes are considerably affected by various factors such as selection of a suitable strain, substrate and process parameters (Pandey et al., 2001). In the present study, optimum temperature, agitation speed and $\mathrm{pH}$ for CGTase production were standardized. Different carbon sources like cassava starch, rice starch, potato starch, corn starch, sago starch, wheat starch, soluble starch and glucose were tried as substrates to increase the enzyme production. Different nitrogen sources such as ammonium salts, tryptone, yeast extract, was studied by supplementing them in the production media. Also effect of percentage of carbon and inorganic and organic nitrogen sources were also done to analyze their influence on CGTase production. Effect of metallic ion concentration was carried out by the addition of $\mathrm{CaCl} 2, \mathrm{MgSO} 4, \mathrm{CuSO} 4, \mathrm{ZnSO} 4$, FeSO4, and MnSO4 to the production media. All the nutritional and physical factors influencing the production of CGTase were standardized by varying one parameter at a time.

\section{Effect of Inoculum Size on CGTase Production}

The effect of initial biomass controls the kinetics of growth and several biological metabolic functions leading to the overall biomass and extracellular enzyme production. The results of experiments conducted with increasing inoculum concentration from $1 \%$ to $10 \%$ and the CGTase activity showed that, CGTase production varied with variation in initial Inoculum level ( Fig:2 ). A maximum enzyme production of $24.73 \mathrm{U} / \mathrm{ml}$ and specific activity $8.49 \mathrm{U} / \mathrm{mg}$ was observed in $4 \%$ initial inoculum supplemented conditions.

\section{Effect of Initial pH on CGTase Production}

The initial $\mathrm{pH}$ and further $\mathrm{pH}$ variation in the culture media plays an important role in the production of CGTase and growth of organism. In order to investigate the optimum $\mathrm{pH}$ for CGTase production by the bacteria, media with $\mathrm{pH}$ adjusted from 4 to 11 was used for the growth of the organism. Fig:3 show the effect of $\mathrm{pH}$ on CGTase production by the isolated bacteria. The organism is able to produce enzyme with maximum activity in a narrow $\mathrm{pH}$ range from $\mathrm{pH} \mathrm{8,9and} \mathrm{10.A} \mathrm{pH}$ of 10.3 was found to be optimum for the enzyme production with $100.405 \mathrm{U} / \mathrm{ml}$.

\section{Effect of Carbon Sources on CGTase Production}

A suitable carbon source is very important for a fermentation process and is very critical if it forms the direct substrate for the product formation. The carbon source was known to be the determining factor inthe rate of CGTase synthesis. Since the production of CGTase did not require the presence of specific inducer, production of the enzyme depends mostly on the substrate used (Kabaivanova et al., 1999). A number of starch types were selected as carbon source, since starch is the main substrate for 
the synthesis of cyclodextrin and the secretion of CGTase. These starch sources were screened for selecting the best one for the maximum production of CGTase in the medium. In the present study eight different carbon sources such as tapioca starch, rice starch, potato starch, corn starch, sago starch, soluble starch, wheat starch and glucosewere used to check the production of CGTase by isolated strain of Leucobacter species. The results are presented in Fig 4 and in Table 1.

It was observed that the bacteria can grow well in media supplemented with most of the types of starch as carbon sources. Studies indicated that Potato starch, corn starch, sago starch, and soluble starch are the most suitable sources for enzyme synthesis. Media with Sago starch showed maximum enzyme activity $(116.12 \mathrm{U} / \mathrm{ml}$ and Specific activity of $37.34 \mathrm{U} / \mathrm{mg}$ ) and media supplemented with potato starch showed enzyme activity close to that of sago starch (115.75 U/ $\mathrm{ml}$ and specific activity of 35 $\mathrm{U} / \mathrm{mg}$ ) on the 5th and 4th day of incubation respectively.

The quality of starch is a key factor in the production of cyclodextrins as evidenced by the earlier works also. Wheat starch gave low yield of CD because of its high amylase content (Szerman et al., 2007). Simple sugar glucose did not produce significant result as summarized in Table: 1and in Fig: 4. But this is in contradictory to a report available for B. stearothermophillus, where glucose was found to be the most suitable substrate (Stefanova et al., 999). However in earlier reports (Jin-Bong et al., 1990; Posci et al., 1988) soluble starch was more suitable for cyclodextrin production by $B$. stearothermophilus. Xylose and glucose were found to be best for B.cereus (Jamuna et al., 1993), but the production was enhanced with addition of starch (Thatai et al., 1999).
Different concentrations of soluble starch on the synthesis of CGTase was tested and results obtained showed an increase in CGTase activity corresponding to the increase in concentration of soluble starch. A high CGTase titre of $123.3 \mathrm{U} / \mathrm{ml}$ and a specific activity of $41.8 \mathrm{U} / \mathrm{mg}$ was obtained in a medium containing soluble starch of $2.5 \%$ as carbon source on the 4th day of incubation. The results are presented in the Figure 5.

Soluble starch concentration above $2.5 \%$ ie $3 \%$ and $5 \%$ in the media showed a drastic decrease in enzyme production. Increased soluble starch concentration resulted in the increment of both CGTase activity and biomass production. However when the concentrations of starch in the feed stream exceed beyond $2.5 \%(\mathrm{w} / \mathrm{v})$, the CGTase activity dropped significantly. High concentration of substrate will reduce the CGTase production due to the increment of viscosities of the culture that lead to poor oxygen uptake. Above a certain concentration of carbon substrate, when other nutrients are kept constant, catabolic repression may occur (Gawande et al., 2001). This may occur due to limitation of other media components in the culture medium. Results of alkalophilic Bacillus sp. (ATCC 31007) reported that soluble starch concentration higher than 20-30 g/ 1 , resulted in low enzyme production. 3\% soluble starch was the best for CGTase production by Bacillus sp TPR71 H (Ravinder et al., 2012). On the other hand $0.1 \%$ sago starch was found suitable for CGTase production by Bacillus lehensis S8 (Yap et al., 2010).

In this study both hydrolyzed and raw forms of different starches such as corn starch, potato starch, sago starch, cassava starch and rice starch were used as substrates for CGTase production. Sago starch was the best among the hydrolyzed starches while 
corn starch was the best substrate as raw starch. In contrast, for Klebsiella pneumoniae As-22 corn starch was not a suitable substrate. It is known that physical treatment makes the starch accessible to CGTase action, while raw starch is inaccessible to the enzyme (Gawande et al., 2001).

\section{Effect of Nitrogen Sources on CGTase Production}

Six different inorganic nitrogen sources like $\mathrm{CH} 3 \mathrm{COONH} 4, \quad$ (NH4)2SO4, $\mathrm{NH} 4 \mathrm{Cl}$, NaNO3, (NH4)2HSO4, and NH4NO3 were used for studying the effect of inorganic nitrogen sources on CGTase production by Leucobacter species. Cell density was high in the media with (NH4)2SO4, (NH4)2HSO4, NH4NO3 and ammonium acetate at $24 \mathrm{~h}$ of incubation and low at NaNO3 supplementation. Maximum CGTase activity reached at the 4th day of incubation in all media. Among the inorganic nitrogen sources (NH4)2HSO4 supplied media gave optimum enzyme activity of $63.47 \mathrm{U} / \mathrm{ml}$ and a specific activity of $18.9 \mathrm{U} / \mathrm{mg}$, which was low when compared with medium lacking inorganic nitrogen sources, and this indicated that this organism does not need any inorganic nitrogen source in the production medium.

Different types of organic nitrogen sources like yeast extract, peptone, yeast extract and peptone, beef extract, malt extract and tryptone were used to evaluate the growth and CGTase production by the strain of bacteria. All the organic nitrogen sources supported the synthesis of CGTase formation by the culture. Cell density was high in the media with yeast extract and peptone, which also proved superior to other substrates with the production of 360 U mL-1 of the enzyme (Fig: 6). Yeast extract alone was found to be best organic nitrogen source next to yeast extract and peptone (355 U/ml). Tryptone containing medium resulted $352 \mathrm{U} / \mathrm{ml}$ CGTase production. Results show that almost all the organic nitrogen sources proved favorable for enzyme production and maximum yield were obtained in the $24 \mathrm{~h}$ of incubation. Further studies were conducted selecting yeast extract and peptone as nitrogen source and its effects were compared..Different concentrations varying from $0.5 \%$ to $3 \%$ were tested for CGTase production. A high CGTase titre of $392 \mathrm{U} / \mathrm{ml}$ of CGTase activity and $140 \mathrm{U} / \mathrm{mg}$ of specific activity was obtained in a medium containing yeast extract and peptone of $0.5 \%$ as substrates. The results were presented in Fig: 7.

In this study enzyme production using inorganic nitrogen sources was found to be low when compared with organic nitrogen sources. It was reported that the best nitrogen source for the production of CGTase was peptone (Illias.et al., 2002). But Mahat et al. (2004), observed that sago starch and yeast extract have a significant effect on CGTase production. In another study it was reported that the best nitrogen source for CGTase production was yeast extract $(1 \% \mathrm{w} / \mathrm{v})$ but went low when ammonium nitrate was used in the production medium (Yap et al., 2010). But earlier it was found that CGTase production was high in $0.5 \%$ yeast extract media which indicates that yeast extract might have some inducer substance or micro nutrients to increase the CGTase production (Ravinder et al., 2012).

\section{Effect of Various Mineral Sources on CGTase Production}

The influence of mineral salts on the production profile of CGTase was investigated by supplementing different metal ions in $10 \mathrm{mM}$ concentration in the 
media. The results presented in Fig: 8 shows that all metal ions inhibited the activity of CGTase. $\mathrm{Mg} 2+$ showed moderate inhibition but $\mathrm{Fe} 2+, \mathrm{Ca} 2+$ and $\mathrm{Zn} 2+$ were the strong inhibitors of CGTase production. This is in accordance with earlier reports (Higuti et al., 2003).

Table.1 Yield of CGTase production using different type of starches.

\begin{tabular}{|l|c|}
\hline Sources of starch & CGTase activity(U/ml). \\
\hline Sago starch & 116 \\
\hline Soluble starch & 115.8 \\
\hline Tapioca starch & 16 \\
\hline Corn starch & 67 \\
\hline Rice starch & 19 \\
\hline Wheat starch & 5 \\
\hline Glucose & 0.4 \\
\hline Potato starch & 102 \\
\hline
\end{tabular}

Fig.1 CGTase production by different isolates in culture filtrates

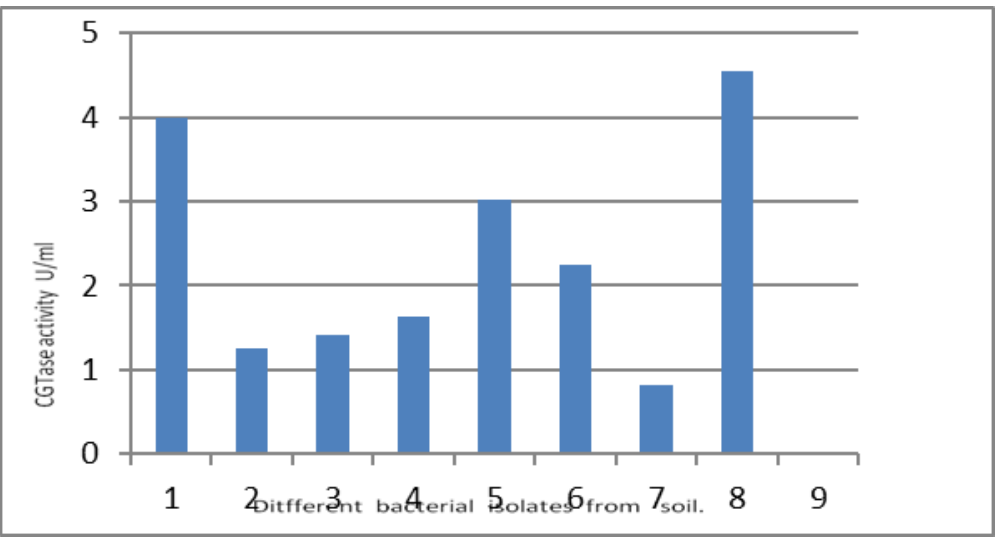

Fig.2 Influence of inoculum size on CGTase production

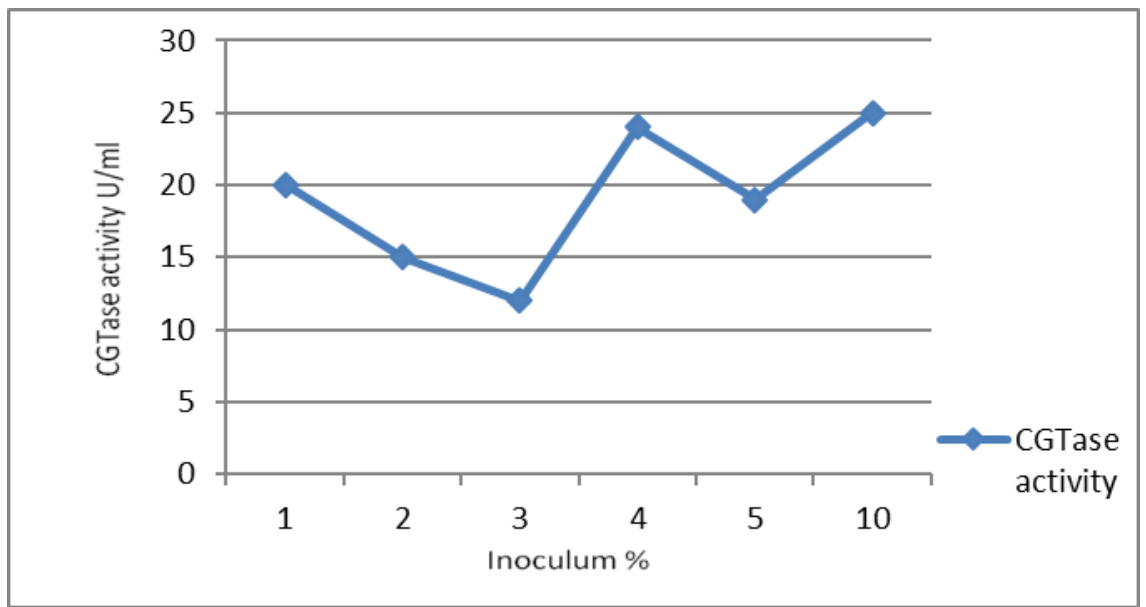


Fig.3 Effect of pH on CGTase production.

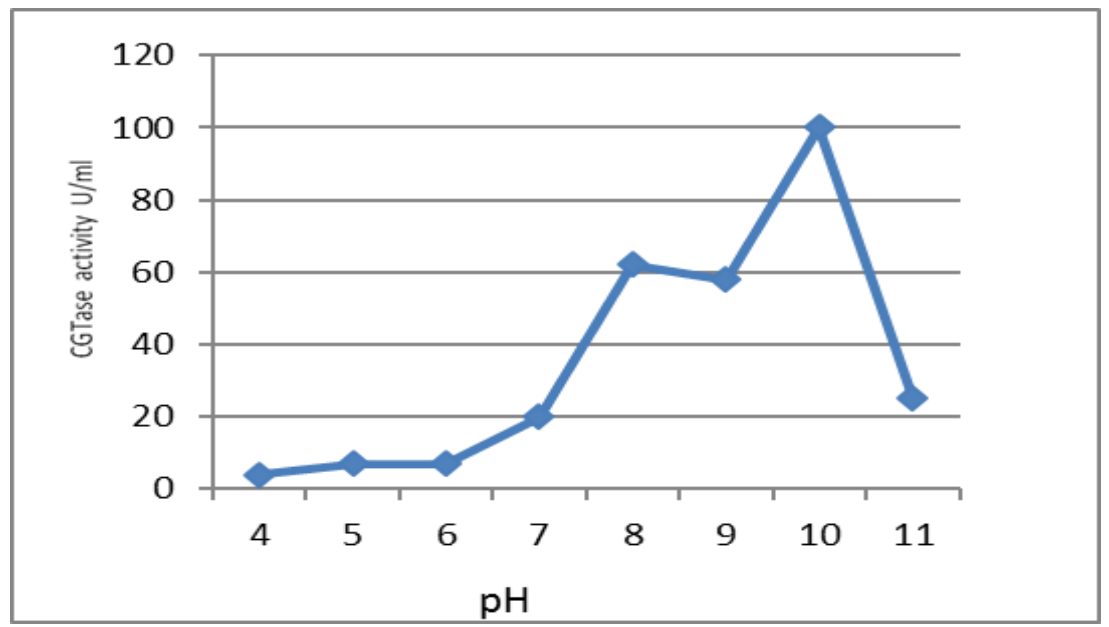

Fig.4 Effect of different carbon sources on CGTase production by Leucobacter sps.

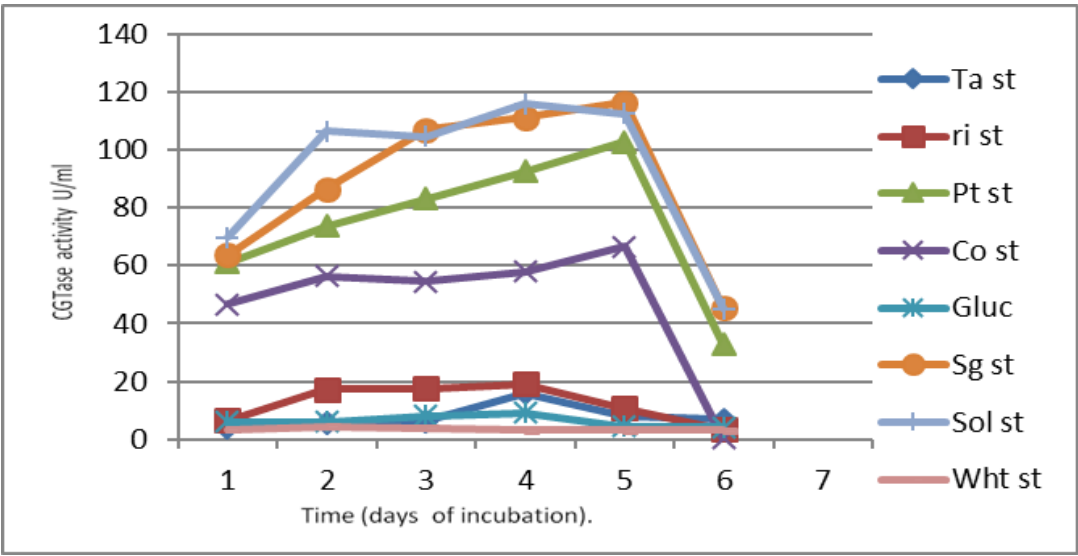

Fig.5 Effect of soluble starch in CGTase production.

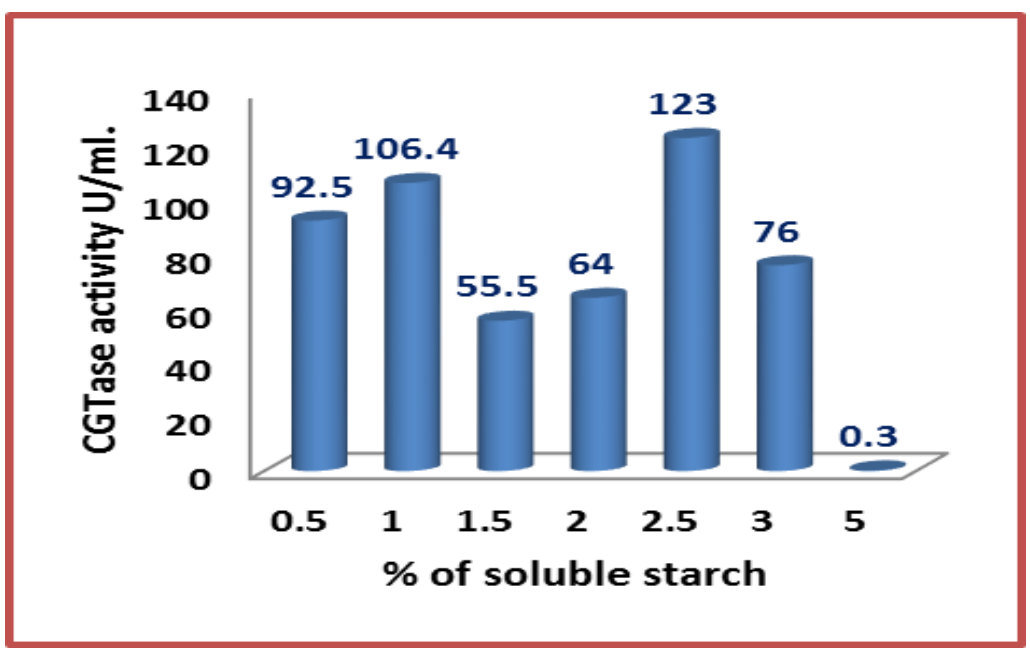


Fig.6 Influence of different nitrogen sources on CGTase production.

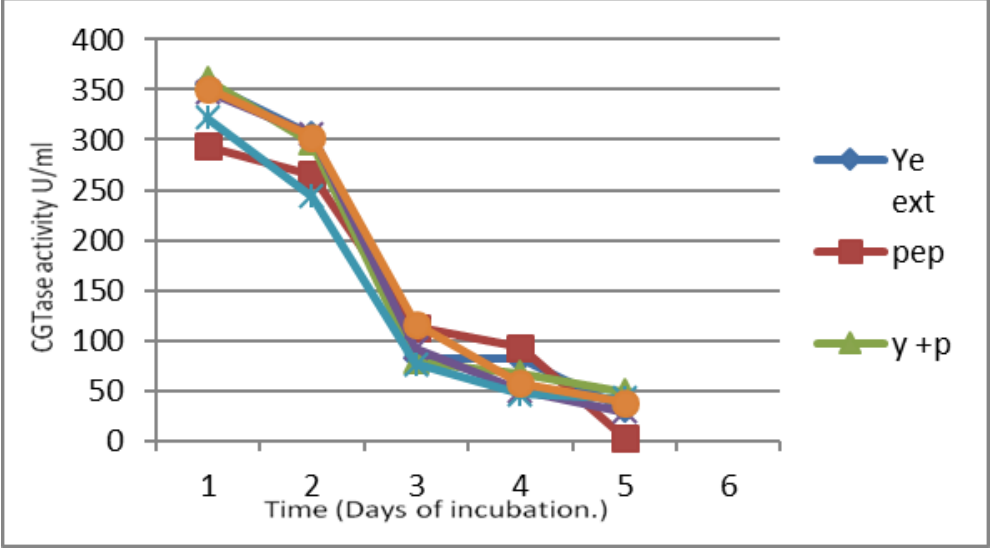

Fig.7 Influence of yeast extract and peptone concentration.

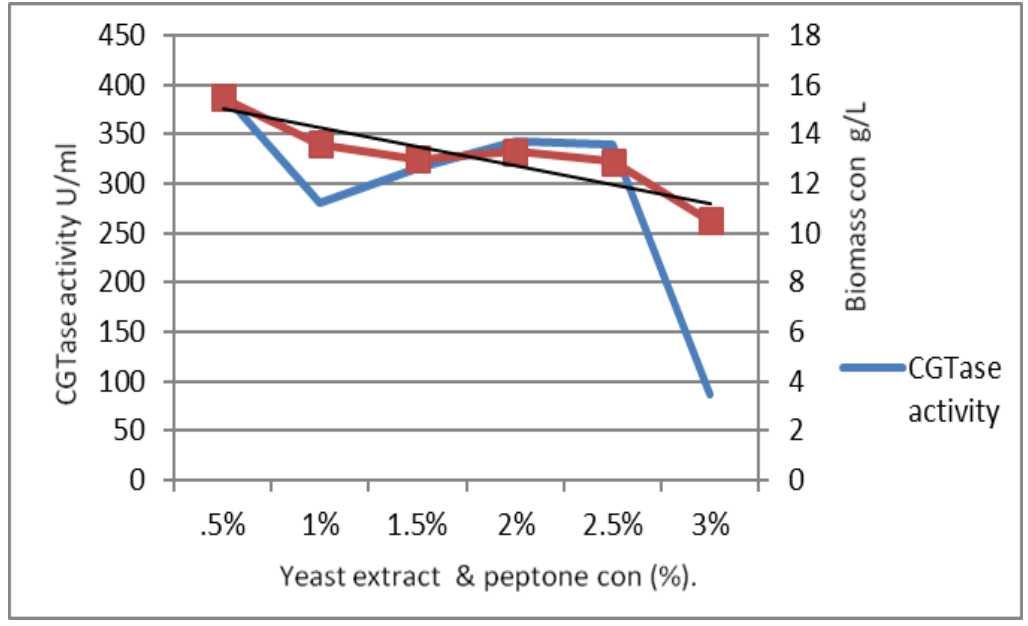

Fig.8 Influence of metal ions on CGTase production.

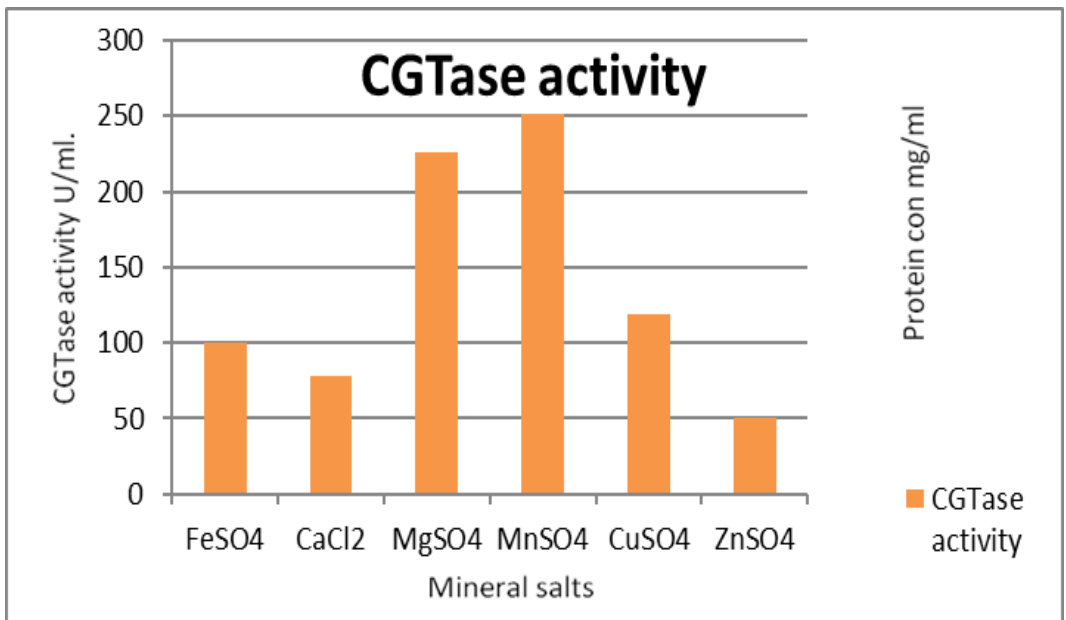


Fig.9 Impact of incubation temperature on CGTase production by Leucobacter sps.

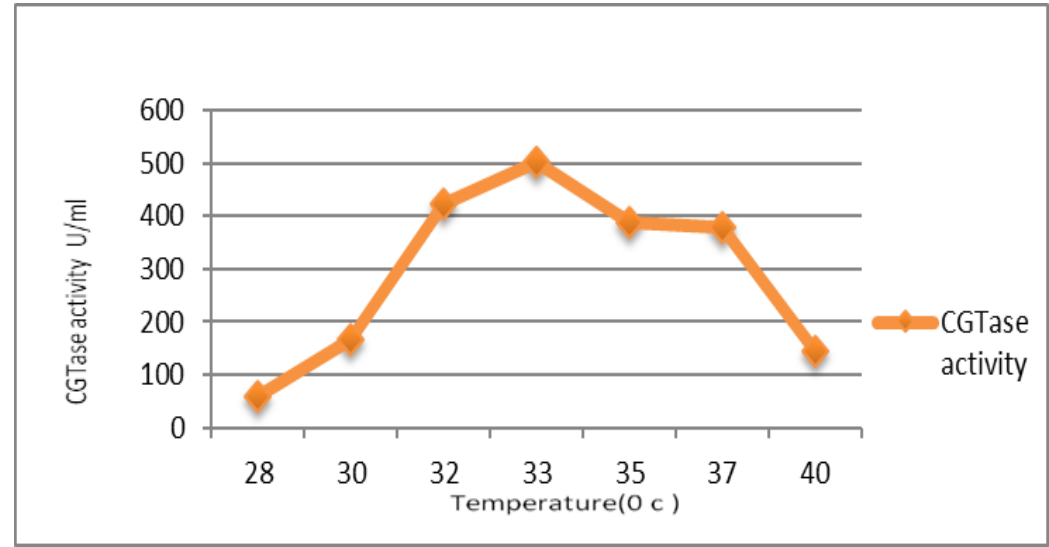

Fig.10 Growth and production profile of CGTase by Leucobacter species.

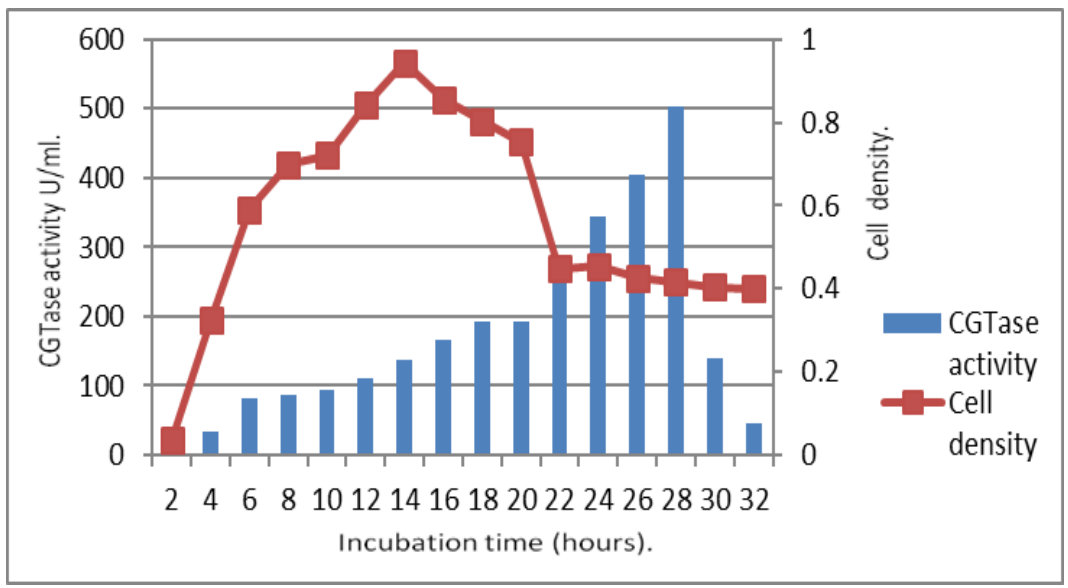

In contrast to the earlier reports (Freitas $e t$ al., 2004) $\mathrm{Mg} 2+$ and $\mathrm{Ca} 2+$ showed little activation of CGTase activity. The effect of metal ions on enzyme activity seems to be depend on the enzyme source (Higuti.et al., 2003 a). The induction of CGTase activity may vary with the nature of organisms (Sivakumar et al., 2011).

\section{Effect of Incubation Temperature on CGTase Production}

In an attempt to understand the relation between production of CGTase and the influence of incubation temperature, isolated culture Leucobacter species was grown at different temperatures ranging from $28^{\circ} \mathrm{C}$ to $40{ }^{\circ} \mathrm{C}$. Figure 9 shows parabolic nature of the enzyme production curve with increase in incubation temperature. Maximum enzyme production of $502.7 \mathrm{U} / \mathrm{ml}$ and a specific activity of $186 \mathrm{U} / \mathrm{mg}$ were noticed at a temperature of $33{ }^{\circ} \mathrm{C}$. Variation of temperature in either side of this resulted in decrease of CGTase production. The loss of activity is more at the lower temperature when compared to higher temperatures.

Different ranges of optimum temperatures were reported for CGTase production. The optimum temperature ranges from $50{ }^{\circ} \mathrm{C}$ for Bacillus firmis (Moriwaki et al., 2007), $70^{\circ} \mathrm{C}$ for Bacillus amyloliquefaciens (Yu et al., 1988), 800c for Bacillus stearothermophilus (Chung et al., 1998) 
and $85^{\circ} \mathrm{C}$ for Thermo anaerobacter (Tardioli et al., 2006). In the present study it is $33^{\circ} \mathrm{C}$.

\section{Growth Profile and CGTase Production by Leucobacter Species}

The above optimized conditions were tested at various time intervals for the production of CGTase. Submerged fermentation was carried out using $2.5 \%(\mathrm{w} / \mathrm{v})$ soluble starch as sole carbon source. The biomass of PK-8 species increased exponentially and reached its maximum value after 24 and $25 \mathrm{~h}$ of incubation (Fig: 10). The CGTase production was $550 \mathrm{U} / \mathrm{ml}$ when growth of microbes entered the late stationary phase. Maximum CGTase activity of $550 \mathrm{U} / \mathrm{ml}$ with specific activity of $212 \mathrm{U} / \mathrm{mg}$ was attained after $27 \mathrm{hr}$. with maximum biomass of $11.5 \mathrm{~g} / \mathrm{L}$. From figure 10, it was observed that during 6 to 15 hours it follows a growth phase, later it attains a stationary phase from 16 to 20 hours of incubation. From 21 to $28 \mathrm{~h}$ enzyme activity increases and further incubation decreased the enzyme production. It may be due to the reduction of nutrients in the medium and formation of protease, which may degrade the CGTase. The results indicate the production of CGTase by the culture was non-growth associated, and maximum CGTase activity was observed during the late stationary phase.

Production of CGTase enzyme followed a similar enzyme production pattern (Fig: 10). The enzyme synthesis begins from the early exponential phase. However the maximum CGTase activity as measured by dextrinizing activity was obtained at 24 to $28 \mathrm{~h}$ of cultivation. From the literature CGTase production by Bacillus cereus was at its peak during the 16 to 20 hour of incubation period (Jamuna et al., 1993). While the alkalophilic species $B$. circulans exhibits enzyme activity after $40 \mathrm{~h}$ of growth with a long lag period (Makela et al.,
1987). Production of CGTase was observed only at the end of the stationary phase for alkalophilic Bacillus sp. G1 (Tien S.F., 2001) and Bacillus agar adherens reaches stationary phase after $11 \mathrm{~h}$ of incubation with maximum enzyme production of $0.31 \mathrm{U} / \mathrm{ml}$ after $25 \mathrm{~h}$ of cultivation (Rita $e t$ al., 2002).

From the above comparisons, CGTase production by Leucobacter species is growth independent as the enzyme production was maximum at the late stationary phase of the cell growth. It is reported that extracellular CGTase are not involved in the degradation of starch in the exponential growth phase of bacteria, because they are usually released into the culture medium when all the starches has been consumed (Nogrady et al., 1995). The enzyme has probably attached to the cell membrane during the exponential phase, it was retained between the cell membrane and the cell wall during the early stationary phase and was only released into the culture medium in the late stationary phase and during the cell lysis.

In conclusion, Optimization of production medium for CGTase synthesis by the newly isolated bacterial strain Leucobacter species was done by submerged fermentation method. Horikoshi medium II which resulted in a high yield of CGTase was further optimized for maximum production of CGTase by conventional method, by changing one independent variable, while fixing others at a certain level. From this study the optimum concentration of carbon and nitrogen sources were observed to be $2.5 \%(\mathrm{w} / \mathrm{v})$ and $0.5 \%(\mathrm{w} / \mathrm{v})$, respectively which lead to the highest CGTase activity of $360 \mathrm{U} / \mathrm{ml}$. This showed an increment of $80 \%$ to the CGTase production after the optimization of $\mathrm{CN}$ ratio in the feeding medium compared to the initial production, which only gave $4.5 \mathrm{U} / \mathrm{ml}$. 
The final composition of the optimized medium to get maximum CGTase by newly isolated bacteria identified as Leucobacter species is consists of soluble starch $2.5 \%$, yeast extract $0.5 \%$, peptone $0.5 \%$, K2HPO4 $0.2 \%, \quad \mathrm{MgSO} 4.7 \mathrm{H} 2 \mathrm{O} \quad 0.01 \%$, with incubation period of $28 \mathrm{~h}$, incubation temperature $33{ }^{\circ} \mathrm{C}$ and $\mathrm{pH} \quad 10.3$ and agitation speed of $130 \mathrm{rpm}$. In this optimized medium and culture conditions, the production of CGTase was found to be 550 $\mathrm{U} / \mathrm{ml}$. The enzyme production was found to be non-growth associated and maximum production occurs during the late stationary phase of cell growth.

\section{References}

Abdel-Naby, M.A., El-Refai, H.A., AbdelFattah, A.F. 2011. Biosynthesis of cyclodextrin glucosyl transferase by the free and immobilized cells of Bacillus cereus NRC7 in batch and continuous cultures. J. Appl. Microbiol., 111(5): 1129-37.

Atanasova, N., Petrova, P., Ivanova, V., Yankov, D., Vassileva, A., Tonkova, A. 2008. Isolation of novel alkaliphilic Bacillus strains for cyclodextrin glucanotransferase production. Appl. Biochem. Biotechnol., 149(2):155-67.

Hamoudi, M., Fattal, E., Gueutin, C, Nicolas, V., Bochot, A. 2011. Beads made of cyclodextrin and oil for the oral delivery of lipophilic drugs: in vitro studies in simulated gastrointestinal fluids. Int. J. Pharm., 20: 416(2):507-14.

Marçon, F., Mathiron, D,. Pilard, S., Lemaire-Hurtel, A.S,. Dubaele, J.M., Djedaini-Pilard, F. 2009. Development and formulation of a $0.2 \%$ oral solution of midazolam containing gamma-cyclodextrin. Int. J. Pharm., 11: 379(2):244-50.
Sian, H., Said, M., Hassan, O., Kamaruddin, K., Ismail, A., Rahman, R. 2005. Purification and characterization of cyclodextrin glucanotransferase from alkalophilic Bacillus sp. G1. Process Biochem., 40:1101-1111. doi: 10.1016/j.procbio.2004.03.018.

Wang, J., Cao, Y., Sun, B., Wang, C. 2011. Physicochemical and release characterization of garlic oil- $\beta$ cyclodextrin inclusion complexes. Food Chem., 127:1680-1685.

Jemli, S., Messaoud, E., Ayadi-Zouari, D., Naili, B., Khemakhem, B., Bejar, S.A. 2007.

$\beta$-cyclodextrin glycosyltransferase from a newly isolated Paenibacillus pabuli US132 strain: Purification, properties and potential use in bread-making. Biochem. Eng. J., 34:44-50. doi: 10.1016/j.bej.2006.11.016.

Schmid, G. 1989. Cyclodextrin glycosyltransferase production: yield enhancement by overexpression of cloned genes. Trends Biotechnol., 7:244-248. doi: 10.1016/01677799(89)90015-2

Andriana, M.R., Susana, A.F., Norberto, K., Clara, B.N. 2002. Optimisation of batch culture conditions for cyclodextrin glucosyltransferase from Bacillus circulans DF 9R. Microl. Cell Fact, 1: 1-9.

Bart, A.V., Joost, C.M.V., Bauke, W.D., Lubbert, D. 2000. Engineering of cyclodextrin glucosyltransferase reaction and product specificity. Biochem. Biophys. Acta, 1543 : $336-$ 360.

Park, S.C., Park, H.H., Kim, S.H. 1989. A rapid screening method for alkaline $\beta$ cyclodextrinsglucanotransferase using phenolphthalein methyl orange containing solid media. Agric. Biol. chem., 53: 1167 - 1169. 
Kaneto, T., Kato, T., Nakamura, N., Horikoshi, K. 1987. Spectrophotometric determination of cyclization activity of $\beta$ cyclodextrins forming cyclomaltodextrin glucanotransferase. J. Jap. Soc. Starch. Sci., 34 (1): 45 - 48.

Lowry, O.H., Rosenbrough, N.J., Farr, A.L., Randall, R.J. 1951. Protein measurement with folin phenol reagent. Biol. chem., 193: 265 -275.

Pandey, A., C.R. Soccl, J.A. Rodriguezleon. Nigan, P. 2001. Solid state fermentation in biotechnology, Fundamental and Application. Asistech Publishers, inc., NewDelhi.

Kabaivanova, L.E., Dobreva, V. Miteva, 1999. Production of $\alpha$-cyclodextrin glucosyltransferase by Bacillus stearothermophilus R2 strain isolated from a Bulgarian hot spring. J. Appl. Microb., 86: 1017 - 1023.

Szerman, N.I., Schroh, A.L., Rossi, A.M., Rosso, N., Krymkiewicz, S.A., Ferrarotti. 2007. cyclodextrin production by cyclodextrin glucosyltransferase from Bacillus circulans DF.9R. Bioresour. Technol., 98: 2886 - 2891.

Stefanova, M.E., Tonkova, A.L., Miteva, V.L., Dobreva, E.P. 1999. Characterization and cultural conditions of a novel cyclodextrins glucanotransferase producing Bacillus stearothermophilus strain. J. Basic Microbiol., 39 (4) : 257 - 263.

Jin - Bong, H., Kim, S.H., Lee, T.K., Yang, H.C. 1990. Production of maltodextrin from Bacillus stearothermophilus. Korean J. Appl. Biotechnol., 18: 578 - 584.

Posci, I., N. Nogrady, A. Liptak, A. Szentirmai. 1988. Cyclodextrins are likely to induce cyclodextrins are likely to induce cyclodextrin glucanotransferase production in
Bacillus macerans. Folia Microb., 43(1) : 71-74.

Jamuna, R.N., Saswathi, R., Sheela, S.V. Ramakrishna. 1993. Synthesis of CGT ase by Bacillus Cercus for the production of cyclodextrins. Appl. Biochem. Biotechol., 43: 163 -176.

Thatai, A., Kumar, M., Mukherjee, K.J. 1999. A single step purification process for Cyclodextrin glucanotransferase from a Bacillus isolated from soil. Preparation Biochem. Biotechnol., 29(1): 35-47.

Gawande, B.N., A.Y., Patkar. 2001. Purification and properties of a novel raw starch degrading Cyclodextrin glucanotransferase from Klebsiella pneumonia AS - 22. Enzyme Microb. Technol., 28: 735 -743.

Ravinder, K., T., Prabhakar, K., Prasanth, Kumar, G.V.P., Bhushan, Venuka, N. 2012. Screening, Isolation and characterisation of cyclodextrin glucosyltransferase producing bacteria from soil samples. Int. J. Pharm. Sci., 4: 408 - 414.

Yap, P.W., A.B., Ariff, K.K., woo, hii, L. 2010. Production of cyclodextrin Glycosyltransferase (CGTase) by Bacillus lehensis using sago starch as carbon source. J. Biol. Sci., 10: 676681.

Illias, R.Md., fen, T.S., Abdul Rasheed, N.A., Yusuff, W.M.W., Hamid, A.A., Hassan, O., Kamarrudeen, K. 2002. cyclodextrin glycosyltransferase producing alkalophilic Bacillus sp.Gl: it's cultural condition and partial characterization of the enzyme. Pak. J. Biol. Sci., 5(6): 688 - 692.

Mahat, M.K., Illias, R.Md, Rahman, R.A., Rashid, N.A., Abd, Mahmood, N.A.N, Hassan, A., Aziz. S.A., Kamarudeen, K. 2004. Production of cyclodrxtrin glucosyltransferase (CGTase) from alkalophilic bacillus 
TS1- 1: media, optimization using experimental design. Enzyme and Microbial Technol., 35: 467 - 473.

Higuti, I.H., Silva, P.A., Nascimento, A.J. 2003. Studies on alkalophilic CGTase producing bacteria and effect of starch on cyclodextrin glucanotransferase activity. Braz. Arch. Biotech.

Freitas, T.L., Monti, R., Contiero, J. 2004. Production of CGTase by a Bacillus alkalophilic CG 11 Strain isolated from waste water of a manioc flour industry. Brazilian J. Microbiol., 35: $255-260$.

Higuti, I.H., Grande, S.W., Sacco, R., Nascimento, A.J. 2003a. Isolation of alkalophilicCGTase producing bacteria and characterization of cyclodextrin glucano transferase. Braz. Arch. Biol. Tech.

Sivakumar, N.S., Banu, 2011. Standardisation of optimum conditions of CGTase production, International Conference on Food engineering and Biotechnology. IPCBEE. 9: IACSIT Press Bangkok, Thailand.

Moriwaki, C., G.L., Costa, R., Pazzetto, G.M., Zanin, F.F., Moraes, M., Portilho, Tiolo, G. 2007. Production and characterization of a new CGTase from Bacillus firmus isolated from Brazilian soil. Process Biochem., 42: $1384-1390$.

Yu, E.K.C.H., Aoki, Misawa, M. 1988. Specific alpha cyclodextrin production by a novel thermostable cyclodextrin glucosyltransferase. Appl. Microbiol. Biotechnol., 28: 377 $-379$.

Chung, H.J., S.H., Yoon, M.J., Kim, K.S., Kweon, I.W., Lee, J.W., Kim, B.H. Oh, H.S., Lee, V.A., Spiridonova, Park, K.H. 1998. Characterisation of thermostable CGT ase isolated from Bacillus stearothermophilus ETI. $J$. Agric. Food. Chem., 46:952 - 959.

Tardioli, E.W., G.M., Zanin, Moraes, F.F. 2006. Characterisation of Thermo anaerobacter cyclodextrin glucanotransferase immobilized on glyoxilagarose. Enzyme. Microbial. Technol., 39: 1270 - 1278.

Makela, M., Korpela, T.K., Laakso, S. 1987. Calorimetric determination of $\beta-$ cyclodextrin; two assay modifications based on molecular complexation of phenolphthalein. J. Biochem. Biophys. Methods, 14: 85-92.

Tien, S.F. 2001. Production of CGTase from alkalophilic Bacillus sp G1 M.Sc. Thesis, University Technology of Malaysia, Malaysia.

Rita, F.M., H.K., Rajni. 2002. A new cyclodextrin glucosyltransferase from an alkalophilic Bacillus agardhaerens isolate: Purification and characterization. Enzyme Microb. Technol., 30: $116-124$.

Nogrady, N.I., Posci, A., Szentirmai. 1995. Cyclodextrin glucosyltransferase may be the only starch degrading enzyme in Bacillus macerans. Biotech. Appl. Biochem., 21: 233-243.

\section{How to cite this article:}

Hazeena, H.S., and Jayakumaran Nair, A. 2016. Production of Cyclodextrin Glycosyltransferase by Newly Isolated Alkalophilic Strain of Leucobacter Species. Int.J.Curr.Microbiol.App.Sci. 5(5): 554-567. doi: http://dx.doi.org/10.20546/ijcmas.2016.505.057 